\section{Cardiac arrest during removal of a pulmonary artery catheter}

Masayasu Nakayama MD, Mako Aimono MD, Shin Kawana MD PhD, Hideya Oomori MD, Hiroaki Watanabe MD PhD, Akiyoshi Namiki MD PhD
Purpose: This case report describes an asystolic cardiac arrest that occurred during removal of a pulmonary artery (PA) catheter.

Clinical features: A 70-yr-old man underwent elective hepatectomy because of hepatic carcinoma with a combination of thoracic epidural blockade and general anaesthesia. After the conclusion of the operation, the PA catheter was removed and immediately after, the patient developed profound sinus bradycardia and hypotension followed by asystolic cardiac arrest. Two minutes after the onset of asystole, cardiac rhythm was detected following the administration of epinephrine and atropine. He had no further episodes of bradycardia or neurological deficit.

Conclusion: Removal of a PA cathether has the potential of inducing asystole requiring cardiac resuscitation and availability of emergency drugs.

Objectif: Signaler un cas d'asystolie pendant le retrait d'un cathéter artériel pulmonaire (AP).

Eléments cliniques: Un homme de 70 ans souffrant d'un carcinome hépatique subissait une hépatectomie sous anesthésie générale combinée à une épidurale thoracique. Après l'opération et immédiatement après le retrait du cathéter $A P$, une bradycardia sinusale et une hypotension profondes s'installaient et étaient suivies d'une asystolie. Deux minutes plus tard, après l'administration d'épinéphrine et d'atropine, on pouvait déceler des battements cardiaques. Il n'y a pas eu d'autres épisodes de bradycardie ni de séquelles neurologique.

Conclusion: Le retrait d'un cathéter AP peut provoquer une asystolie nécessitant une réanimation cardiaque et un besoin urgent de médicaments.

\section{Key words}

EQUIPMENT: catheters, pulmonary artery; COMPLICATIONS: cardiac arrest.

From the Department of Anesthesiology, Sapporo Medical University School of Medicine.

Address correspondence to: Dr. Masayasu Nakayama, Division of Anesthesia, Nikko Memorial Hospital, 1-5-13, Shintomi-cho, Muroran, 051, Japan.

Phone: 0143-24-1331. Fax: 0143-24-1064.

Accepted for publication 11 th May, 1996.
Several complications have been described following pulmonary artery (PA) catheterization, including thrombus formation, balloon rupture, intracardiac knotting of a catheter and pulmonary artery injuries. ${ }^{1,2}$ Ventricular arrhythmias are the most common complication associated with PA catheterization. ${ }^{1,2}$ Although catheterinduced persistent ventricular tachycardia and ventricular fibrillation have been reported, ${ }^{3-8}$ this is the first report describing asystolic cardiac arrest occurring during removal of a PA catheter.

\section{Case report}

A 70-yr-old, 52-kg man was scheduled for elective hepatectomy because of hepatic carcinoma. His medical history was unremarkable except for papillotomy for common bile duct stones two years previously. Preoperative assessment, including physical examination, electrolytes, and blood count, was normal. A 12-lead ECG revealed regular sinus rhythm with a heart rate (HR) of 70 beats $\cdot \mathrm{min}^{-1}$ and no conduction disturbance was recognized

Upon arrival in the operating room, continuous ECG (lead II), arterial blood pressure (AP), and arterial oxygen saturation monitoring were started. An epidural catheter was inserted from the $T_{11-12}$ interspace and 12 ml lidocaine $1.5 \%$ with 1:200,000 epinephrine was injected, resulting in a sensory block from $T_{4}$ to $L_{3}$ followed by slowing of HR from 90 beats $\cdot \mathrm{min}^{-1}$ to 70 beats $\cdot \mathrm{min}^{-1}$ after $15 \mathrm{~min}$. Ten milliliters of the same local anaesthetic solution were added every hour during the operation. General anaesthesia was induced with thiamylal $i v$ and maintained with isoflurane and nitrous oxide in oxygen. Vecuronium provided neuromuscular relaxation. A 8.0-French catheter introducer was inserted into the right internal jugular vein and a 7.0-French thermodilution flow-directed PA catheter (Baxter Healthcare Corp., Irvine, CA), which was not heparincoated, was placed through the introducer while monitoring the pressure wave without complications. No haemodynamic problems were encountered throughout the operation. Pulmonary capillary wedge pressure was maintained between 13 and $17 \mathrm{mmHg}$ throughout the operation.

The operation was concluded after six hours, at which 
time the PA catheter was removed. No abnormality in ECG including left bundle branch block was seen before removal of the PA catheter. Immediately after, the patient developed profound sinus bradycardia (HR, from 100 beats $\cdot \mathrm{min}^{-1}$ to 30 beats $\cdot \mathrm{min}^{-1}$ ) and hypotension (AP, from $120 / 65 \mathrm{mmHg}$ to $60 / 25 \mathrm{mmHg}$ ). Immediate administration of $5 \mathrm{mg}$ ephedrine $i v$ failed to increase HR and AP. In a few seconds, asystolic cardiac arrest followed. Chest compressions were begun, and the patient's lungs were ventilated with $100 \%$ oxygen. Epinephrine, $0.1 \mathrm{mg}$, and atropine, $0.5 \mathrm{mg}$, were administered $i v$. Cardiac rhythm was detected approximately two minutes after the onset of asystole, followed by sinus tachycardia (150 beats $\left.\cdot \mathrm{min}^{-1}\right)$ and systemic hypertension $(180 / 110 \mathrm{mmHg})$. Nicardipine, in $0.5 \mathrm{mg}$ $i v$ increments, was used to control AP.

The HR subsequently stabilized between 100 and 120 beats $\min ^{-1}$. Serum electrolytes, arterial blood gas analysis and haemoglobin concentration were unremarkable. Because there were no signs of acute cardiac tamponade, such as jugular veins distention, a paradoxical pulse, and a low-voltage QRS complex, we did not carry out an echocardiogram. The patient was transferred to the intensive care unit with his trachea intubated. He had no further episodes of bradycardia. A 12-lead ECG and serum enzymes were normal. There was no detectable neurological deficit.

\section{Discussion}

Damen ${ }^{9}$ reported that the incidence of ventricular arrhythmias during insertion of PA catheters was $66 \%$, and similar to the incidence during removal. A ventricular premature contraction exhibiting $R$ on $T$ can initiate ventricular tachycardia or fibrillation. However, it seems unlikely that bradycardia followed by asystole occurred immediately after ventricular arrhythmia. In addition, no ventricular arrhythmia was observed at removal of the PA catheter in our patient.

The abrupt onset of bradycardia and asystole suggests a reflex phenomenon. Stimulation of the carotid sinus by stretching increases parasympathetic activity and decreases the heart rate. Thus, compression of the neck during and after removal of the PA catheter could induce a parasympathetic reflex. The patient received thoracic epidural anaesthesia with an anaesthetic level $\geq T_{4}$, which blocked cardiac sympathetic fibres and this may emphasize the parasympathetic reflex.

Mackey et al.,$^{10}$ reported profound bradycardia and asystole following spinal anaesthesia and suggested that the Bezold Jarisch reflex was a possible cause. The classical Bezold Jarisch reflex arises from mechanoreceptors and chemoreceptors located primarily in the inferoposterior wall of the left ventricle. Stimulation of these receptors, by stretching or chemical substances, increases parasympathetic activity and inhibits sympathetic activity, producing bradycardia, systemic vasodilatation and hypotension. ${ }^{10}$ The Bezold Jarisch reflex is also reported to be induced by pulmonary embolism. ${ }^{11}$ Thrombosis is one of the most common complications associated with the PA catheter. ${ }^{12,13}$ Thus, when the catheter is removed, the thrombi might embolize in the pulmonary circulation and cause a Bezold Jarisch reflex. Our use of a non-heparin-coated PA catheter seems to strengthen this possibility. Increased parasympathetic activity by compression of the neck and epidural anesthesia may emphasize the reflex and cause bradycardia to proceed to asystole.

Sudden cardiac arrest has been reported in patients with autonomic dysfunction. ${ }^{10}$ Although the patient had no accompanying clinically apparent autonomic dysfunction, he was 70-yr-old and aging impairs autonomic function. ${ }^{14}$ Decreased sensitivity to $\beta$-adrenergic receptors accounts for the endogenous $\beta$-adrenergic blockade of aging. Elderly patients have a lower chronotropic response to isoproterenol than the young. The underdamped and less tightly self-regulated autonomic nervous system in the patient could be, at least in part, responsible for the propensity for bradycardia and asystole.

We conclude that asystole can occur during removal of a PA catheter. Although the exact pathophysiological mechanism of asystole is not known, risk factors for this phenomenon are thought to be high epidural blockade, thrombus formation on the PA catheter, and aging which increase parasympathetic activity. We recommend that the PA catheter be removed in an environment where drugs for treatment of asystole, such as atropine and epinephrine, are avaliable. Moreover, care should be taken to avoid excessive compression of the carotid sinus.

\section{References}

1 Shah KB, Rao TLK, Laughlin S, El-Etr AA. A review of pulmonary artery catheterization in 6,245 patients. Anesthesiology 1984; 61: 271-5.

2 Slung $H B$, Scher KS. Complications of the Swan-Ganz catheter. World J Surg 1984; 8: 76-81.

3 Katz JD, Cronau LH, Barash PG, Mandel SD. Pulmonary artery flow-guided catheters in the perioperative period. JAMA $1977 ; 237: 2832-4$.

4 Cairns JA, Holder D. Ventricular fibrillation due to passage of a Swan-Ganz catheter (Letter). Am J Cardiol 1975; 35: 589 .

5 Sprung $C L$, Jacobs $L$, Caralis PV, Karpf $M$. Ventricular arrhythmias during Swan-Ganz catheterization of the critically ill. Chest 1981; 79:413-5. 
6 Sprung CL, Pozen RG, Rozanski JJ, Pinero JR, Eisler BR, Castellanos $A$. Advanced ventricular arrhythmias during bedside pulmonary artery catheterization. Am J Med 1982; 72: 203-8.

7 Sise MJ, Hollingsworth P, Brimm JE, Peters RM, Virgilio $R W$, Shackford SR. Complications of the flow-directed pulmonary-artery catheter: a prospective analysis in 219 patients. Crit Care Med 1981; 9: 315-8.

8 Borkowski $P$, Wiernikowski A. Cardiac arrest during introduction of Swan-Ganz catheter into the pulmonary artery. (Polish) Kardiologia Polska 1978; 21: 151-3.

9 Damen J. Ventricular arrhythmias during insertion and removal of pulmonary artery catheters. Chest $1985 ; 88$ : 190-3.

10 Mackey DC, Carpenter RL, Thompson GE, Brown DL, Bodily $M N$. Bradycardia and asystole during spinal anesthesia: a report of three cases without morbidity. Anesthesiology 1989; 70: 866-8.

11 Simpson RJ, Podolak R, Mangano CA Jr, Foster JR, Dalldorf $F G$. Vagal syncope during recurrent pulmonary embolism. JAMA 1983; 249: 390-3.

12 Lange HW, Galliani CA, Edwards JE. Local complications associated with indwelling Swan-Ganz catheters: autopsy study of 36 cases. Am J Cardiol 1983; 52: 1108-11.

13 Chastre J, Cornud F, Bouchama A, Viau F, Benacerraf $R$, Gibert $C$. Thrombosis as a complication of pulmonaryartery catheterization via the internal jugular vein. $\mathrm{N}$ Engl J Med 1982; 306: 278-81.

14 Muravchick $S$. Anesthesia for the elderly. In: Miller RD (Ed.). Anesthesia, 4th ed. New York: Churchill Livingstone Inc., 1994: 2143-56. 